\title{
STUDENTS' PERCEPTIONS OF THE PROJECT BASED ON THE POTENTIAL OF THEIR REGION: A PROJECT-BASED LEARNING IMPLEMENTATION
}

\author{
Syahril(D, Rahmat Azis Nabawi (D), Dian Safitri (D) \\ Universitas Negeri Padang (Indonesia) \\ Syahri@@ft.unp.ac.id,raazna@ft.unp.ac.id,diansafitri@fbs.unp.ac.id
}

Received November 2020

Accepted April 2021

\section{Abstract}

Developing engineering students whose ability to work and make a real contribution to the development of technology can be done not only after they have graduated from college but also when they are still in college. One of the strategies is by implementing project-based learning with the project based on the potential of the student's region. This study aims to reveal students' perceptions of learning and soft skills acquisition toward the implementation of the strategy to answer whether the project is effective to implement. This study was conducted on fifty-one Indonesian college students who took Mechanical Drawing course. It belongs to a one-shot case study with mixed-method approach. The result shows that the project based on the potential of the student's region is effective to raise their perception of motivation, interest, real-world, very beneficial, learning more lecture and enjoyable so that they learn more actively and provide more time to study. It also develops students' soft skills, including teamwork, project management, communication, and interpersonal skills. The results may have pedagogical implications in improving learning quality in Mechanical Drawing course by enriching project references used in implementing project-based learning. Furthermore, the project given can be a solution in developing the potential of the students' regions.

Keywords - Project-based learning, Mechanical engineering, Students' perception, Soft skills.

\section{To cite this article:}

Syahril, Nabawi, R.A., \& Safitri, D. (2021). Students' perceptions of the project based on the potential of their region: A Project-based learning implementation. Journal of Technology and Science Education, 11(2), 295-314. https://doi.org/10.3926/jotse.1153

\section{Introduction}

The potential of a region is a valuable asset and competitive advantage possessed by a certain region (Botezat \& Benea, 2012; Gupta, 2017). Educational institutions need to see this as an opportunity to be used as a teaching topic in learning activities because essentially, schools as official education institutions must be able to encourage students to always be close and interact with local wisdom (Mackenzie, Pidd, Rooksby, Sommerville, Warren \& Westcombe 2003). Education is an important asset to develop interpersonal and intrapersonal intelligence in various fields of life to be able to develop existing potential (Pornpimona, Wallapha \& Prayuth, 2014). Many experts have discussed the relationship of education to 
the economic development of a country (Fjellström, 2014; Behroozi, 2014). The role of education in developing the potential of the region is an added value for the institution as its main task is to create students who have competencies. The important task of a college is to provide innovative learning for the students so that they can improve their competitiveness in entering the job market and encourage long-term social development (Crosling, Nair \& Vaithilingam, 2015).

Mechanical Drawing is a compulsory subject in the Department of Mechanical Engineering. Learning activities in this subject are designed to train students to have the competence to be able to draw a design of components, tools, or machines that are under standards using Computer-Aided Design based software. To be able to increase students' interest in mechanical drawing learning, learning activities can be carried out by implementing project-based learning (PjBL) (Santos, Goncalves, Oliveira \& Silva, 2018). $\mathrm{PjBL}$ is generally suitable for core courses in engineering (Hanney, 2018). PjBL does not only increase students' motivation but also increases their problem-solving skills (Chiang \& Lee, 2016). A study by Kuppuswamy and Mhakure (2020) reveals that the implementation of PjBL helps college students to practice their knowledge in a design product project. Besides, research by Qiang, Tan, Shi, Zhou, Lin and $\mathrm{Ma}$ (2020) finds that by PjBL, college students feel motivated and it can be implemented in other engineering courses. It is also able to help students designing a new model of the project and getting problem-solving skills (Sharma, Dutt, Sai \& Naik, 2020).

$\mathrm{PjBL}$ is a learning model that can improve learning quality in higher education (Guo, Saab, Post \& Admiraal, 2020). An innovative independent learning aspect of PjBL is not only for post-graduates but also for undergraduate students (Castaldi \& Mimmo, 2019). In running the project, the students can do self-monitoring and self-management effectively (Cifrian, Andres, Galán \& Viguri, 2020). Its process also improves the relationship among students, communication between students and lecturers, and a constructive learning atmosphere where the students are independently learning (Requies, Agirre, Barrio \& Graells, 2018). Besides, empirical proof shows that PjBL can improve students' interest, experience, and participation in learning (Rambocas \& Sastry, 2017).

$\mathrm{PjBL}$ requires students to deal with real issues and questions that are relevant to the topics being studied (Milentijevic, Ciric \& Vajinovic, 2008). By involving students in projects from real life and in active inquiry, they will be fostered to learn actively, think critically, and have problem-solving skills (Uziak, 2016). PjBL directs students to be involved in analyzing a project and finding possible solutions (Amamou \& Belcadhi, 2018). PjBL has a strong potential to solve real-world problems through students' projects (Jalinus \& Nabawi, 2017; Syahril, Nabawi \& Prasetya, 2020). Learning Mechanical Drawing subject with the implementation of PjBL can lead to projects of the potential of students' regions.

This study aims to reveal students' perceptions of the project of the potential in their regions. The learning activities are carried out by implementing PjBL with the project based on the potential from each region of the students. This orientation is a renewable action and students' perception of the learning activities needs to be revealed. Through this project, students are expected to care about their region and educational institutions, leading to a positive effect, which is to contribute significantly to developing the potential of their region. To achieve the goal, below are the research questions to answer:

1. What are the students' perceptions of learning toward the implementation of $\mathrm{PjBL}$ with the project based on the potential of their region?

2. What are the student's perceptions of soft-skills acquisition toward the implementation of PjBL with the project based on the potential of their region?

\section{Method}

\subsection{Participants}

51 students were taking the Mechanical Drawing course at Mechanical Engineering Department of Universitas Negeri Padang, Indonesia as participants. The students are freshmen and come from different regions in Indonesia. The study was conducted for 16 meetings or a semester, three credits per meeting. 


\subsection{Design}

This study belongs to a one-shot case study with a mixed-method approach. Campbell and Stanley (1966) explain one-shot case study as a part of quasi-experimental research that uses a one-group posttest only design in which the researcher measures a dependent variable for one group of participants following a treatment. Meanwhile, the mixed-method used here refers to what Creswell and Plano (2011) state that it uses both quantitative and qualitative approaches in conducting the research. Integrating two or more methods in research will increase the confidence of having a valid result and not only the problems of methodological artifacts (Bouchard, 1976). Qualitative methods are used to get a better understanding of the results of quantitative research (Creswell \& Plano, 2011). Qualitative research was conducted by using content analysis method. Schreier (2012) states that content analysis method can be used to analyze and interpret the meaning of qualitative data. The method has a systematic and objective way to describe and measure phenomena (Downe-Wamboldt, 1992). The content analysis research phase follows the stages developed by Elo, Kääriäinen, Kanste, Pölkki, Utriainen and Kyngäs (2014), namely preparation, organizing, and reporting the results. Also, to increase the trustworthiness of the results, each phase of the study refers to the checklist developed by Elo et al. (2014). In this study, to get a valid result, a deep interview was conducted with the participants to support their responses to the questionnaire given before. To maintain objectivity, the researchers were assisted by two related experts whose roles were to distribute the questionnaires, review the learning activities, conduct the interview, and analyze the research results.

\subsection{Collection and Analysis of Quantitative Data}

\subsubsection{The Questionnaire of Students' Perceptions of the Project Based on the Potential of their Region}

The questionnaire used in this study referred to the questionnaire of Sang and Van (2016) and was modified in line with the students' projects. There were two dimensions used in this questionnaire; students' perceptions and students' soft skills acquisition. In the first dimension, motivation and interest are added to the statements. Likert Scale was used with point scales: strongly agree (5), agree (4), neutral (3), disagree (2), and strongly disagree (1). The questionnaire was validated by five experts who are associate professors from Universitas Negeri Padang with 30-40 years of experience in research and teaching. The judgment was decided by exploring each item following the aspect of the ease to understand in terms of language structure, the association of items and dimensions or statements measured, the affordability of items to measure each dimension or statement, and those items are important to include (Fernández-Gómez, MartínSalvador, Luque-Vara, Sánchez-Ojeda, Navarro-Prado \& Enrique-Mirón 2020). The data analysis was done by using Aiken coefficient. The result shows that the Aiken coefficient is 0.89 on average. The questionnaire reliability was tested by using Cornbach's alpha to see the conformity with the research questions (Cronbach, 1951). Cornbach's alpha has been used a lot in studies in science education to see whether the questionnaire is reliable (Taber, 2018). Cronbach's alpha which is more than 0.7 is regarded as sufficient (Nunnally \& Bernstein, 1994). Cronbach alpha of each statement ranges between .888 and .952 . This indicates that the data obtained is trustworthy. The statements on every dimension are shown in Table 1.

\begin{tabular}{|c|c|c|c|}
\hline Dimensions & Statements & No. of items & Reliability \\
\hline \multirow{6}{*}{$\begin{array}{l}\text { Student's perceptions of learning toward the } \\
\text { implementation of PjBL with the project based on } \\
\text { the potential of their region? }\end{array}$} & Motivation & 1 & .952 \\
\hline & Interest & 1 & .948 \\
\hline & Real-world & 1 & .945 \\
\hline & Learn more lecture & 1 & .949 \\
\hline & Very beneficial & 1 & .952 \\
\hline & Enjoyable & 1 & .943 \\
\hline \multirow{4}{*}{$\begin{array}{l}\text { Student's perceptions of soft-skills acquisition } \\
\text { toward the implementation of PjBL with the project } \\
\text { based on the potential of their region? }\end{array}$} & Teamwork & 4 & .888 \\
\hline & Project management & 4 & .904 \\
\hline & Communication skills & 5 & .900 \\
\hline & Interpersonal skills & 5 & .936 \\
\hline
\end{tabular}

Table 1. Dimensions statement Cronbach's alpha coefficients of students' perception 


\subsubsection{The Data Analysis}

The result of the questionnaire of students' positive perceptions was quantitatively analyzed by using percentage, average, standard of deviation, and relevant statistic methods. To see the correlation between learning and soft skills, and how much the influence was analyzed by using correlation and linear regression. Hypotheses of correlation and regression analysis on student's perceptions of the learning with the project based on the potential of their region by the acquisition of soft skills are shown in Table 2 .

\begin{tabular}{|c|c|c|c|}
\hline \multicolumn{2}{|c|}{ Variables } & \multicolumn{2}{|c|}{ Hypothesis } \\
\hline Independent & Dependents & Hypothesis Null $\left(\mathrm{H}_{0}\right)$ & Hypothesis Alternative (Ha) \\
\hline \multirow{4}{*}{$\begin{array}{l}\text { Student's } \\
\text { perceptions of } \\
\text { the learning with } \\
\text { the project based } \\
\text { on the potential } \\
\text { of their region }\end{array}$} & Teamwork & $\begin{array}{l}\text { There is no statistically significant } \\
\text { contribution of Student's } \\
\text { perceptions of the learning with the } \\
\text { project based on the potential of } \\
\text { their region on teamwork }\end{array}$ & $\begin{array}{l}\text { There is a statistically significant } \\
\text { contribution of Student's perceptions } \\
\text { of the learning with the project } \\
\text { based on the potential of their region } \\
\text { on teamwork }\end{array}$ \\
\hline & $\begin{array}{l}\text { Project } \\
\text { management }\end{array}$ & $\begin{array}{l}\text { There is no statistically significant } \\
\text { contribution of Student's } \\
\text { perceptions of the learning with the } \\
\text { project based on the potential of } \\
\text { their region on project management }\end{array}$ & $\begin{array}{l}\text { There is a statistically significant } \\
\text { contribution of Student's perceptions } \\
\text { of the learning with the project } \\
\text { based on the potential of their region } \\
\text { on project management }\end{array}$ \\
\hline & $\begin{array}{l}\text { Communication } \\
\text { skills }\end{array}$ & $\begin{array}{l}\text { There is no statistically significant } \\
\text { contribution of Student's } \\
\text { perceptions of the learning with the } \\
\text { project based on the potential of } \\
\text { their region on communication skills }\end{array}$ & $\begin{array}{l}\text { There is a statistically significant } \\
\text { contribution of Student's perceptions } \\
\text { of the learning with the project } \\
\text { based on the potential of their region } \\
\text { on communication skills }\end{array}$ \\
\hline & Interpersonal skills & $\begin{array}{l}\text { There is no statistically significant } \\
\text { contribution of Student's } \\
\text { perceptions of the learning with the } \\
\text { project based on the potential of } \\
\text { their region on interpersonal skills }\end{array}$ & $\begin{array}{l}\text { There is a statistically significant } \\
\text { contribution of Student's perceptions } \\
\text { of the learning with the project } \\
\text { based on the potential of their region } \\
\text { on interpersonal skills }\end{array}$ \\
\hline
\end{tabular}

Table 2. Variables Hypotheses

\subsection{Data Collection and Analysis Method for Content Analysis}

In content analysis study, the data collection can be done by using semi-structured interviews (Neuendorf, 2002; Elo \& Kyngäs, 2008; Elo et al., 2014). The outline of the interview was written to get information about students' opinions and experiences related to the implementation of the project based on the potential of their region. As the goal, the interview questions were compiled based on what they thought and experienced during doing the project. In collecting the data by using semi-structured interviews, the interviewer was careful not to direct participants' answers (Pyett, 2003). The 13 interviewees were numbered I-1 to I-13. This number is enough to provide the data needed in the quantitative study as Lapan, Quartaroli and Riemer (2012) say that a semi-structured interview is used to collect information with twelve to fifteen interviewees. The outline consists of the following questions:

1) What do you think about the project based on the potential of your regions?

2) What do you think about the classroom learning activities in which the project was implemented?

3) What were your motivation and interest in doing this project?

4) How did you identify the potential of your region to be raised in the project?

5) How could you find the ideas to be realized in the project?

6) How did you do the project well and ontime?

In accordance with the content analysis phase proposed by Elo et al. (2014), the data obtained from the semi-structured interviews were then organized. The data analysis in the organization phase was carried 
out by four researchers. This is based on what Burla, Knierim, Barth, Duetz and Abel (2008) and Schreier (2012) state that to reach comprehensive data and proper interpretation, data analysis must be carried out by more than one person.

\subsection{The potential of the Students' Regions as the Project of Implementing PjBL}

There are seven syntaxes of learning in implementing PjBL, such as: formulating expected learning outcomes, understanding the concept of teaching materials, training skills, designing the project-based theme, marking the project proposal, executing the tasks of projects, and presenting the project report (Jalinus \& Nabawi, 2018). Project task based on the potential student's region is a learning model that allows students to design and create a tool or machine that can develop their regional potential (Syahril et al., 2020). PjBL becomes the reference in conducting Mechanical Drawing course. The learning design with the implementation of $\mathrm{PjBL}$ can be seen in Figure 1. The first syntax, formulating expected learning outcomes was done in the first meeting within several activities such as discussing the lesson plan and the potential of the students' regions that will be their project during the semester. Then, the students were instructed to start surveying their area to figure out the potential sources that they could develop. At the end of the meeting, they were divided into groups to discuss the topics of materials and prepare the presentation about it in the next meeting. The second syntax, understanding the concept of teaching materials was conducted in the second and the third meeting. Learning activity in this syntax is debriefing the students' cognitive skills about the theory of mechanical drawing. The third syntax was training skills. The students practiced designing and drawing the picture of the machine.

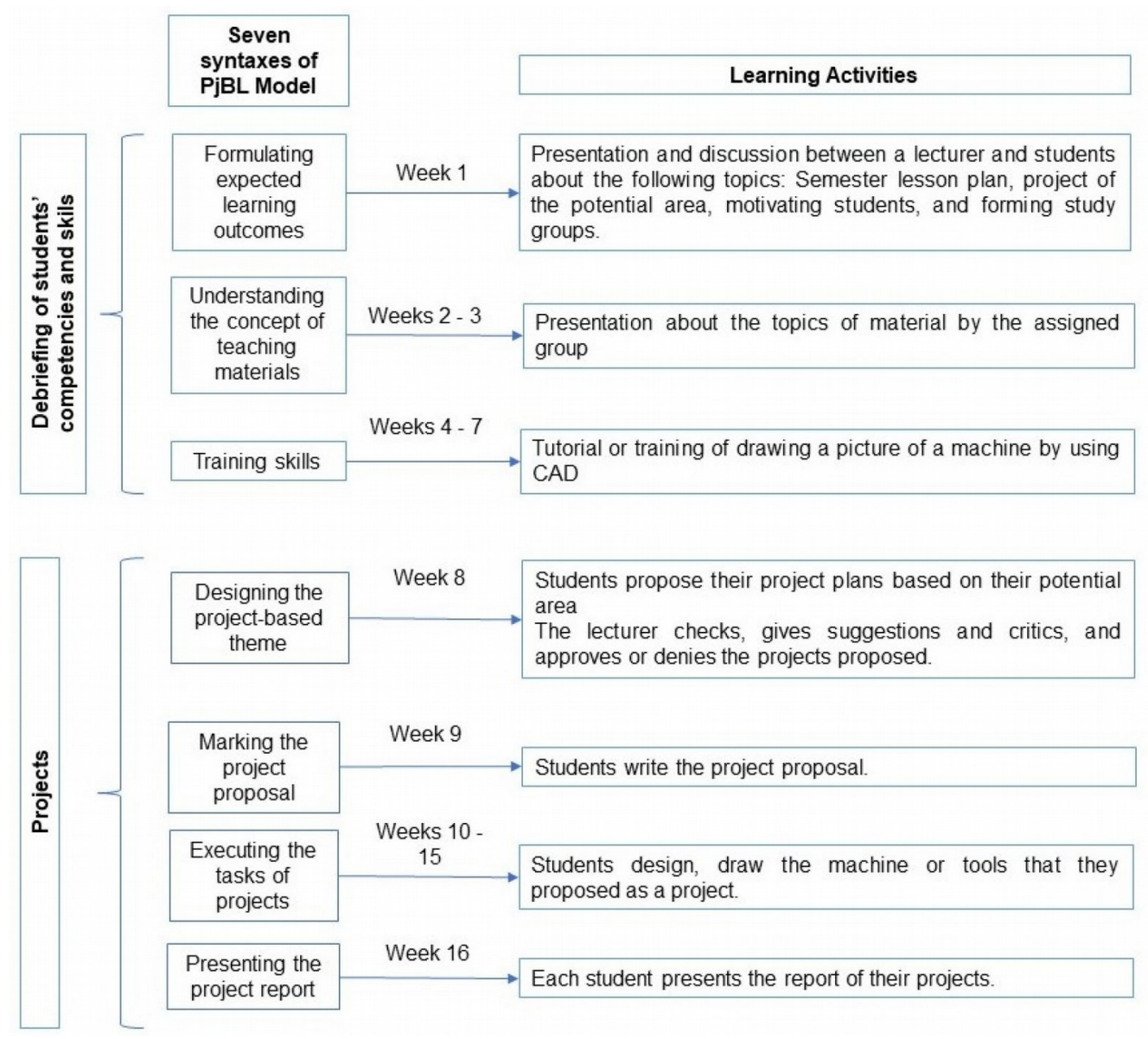

Figure 1. The implementation of the seven syntaxes of PjBL in Mechanical Drawing course

The fourth syntax was designing the project-based theme. In this stage, students proposed their project plans which talked about the potential of their region. They presented the potential sources of their 
region and the design of the machine they would develop. The lecturer and other students gave comments and suggestions about the presentation. Every plan was considered to be approved or not. If it was rejected, the students could propose another project which was suitable for the indicators given.

The next syntax, making the project proposal, led the students to write the project proposal based on what had been previously approved by the lecturer. If the criteria were completed, the lecturer could approve and the students could continue to the next syntax. The sixth was executing the tasks of the projects. In this stage, the students did the project to draw in detail from a machine or tool to develop the potential sources in their region. The last syntax was presenting the project report. Every student presented their project report in the classroom.

\section{Finding and Discussion}

\subsection{Students' Perceptions Toward the Implementation of PjBL with the Project Based on the Potential of the Students' Regions}

The data analysis of students' perceptions is presented in Table 3. The result shows that the highest score is motivation $(M=4.61)$ in which $60.8 \%$ of the students agreed and $39.2 \%$ disagreed. This was followed by interest $(M=4.57)$, real-world $(M=4.47)$, enjoyable $(M=4.43)$, very beneficial $(M=4.41)$, and learning more lecture $(M=31)$.

\begin{tabular}{|l|c|c|c|c|c|c|c|}
\hline \multicolumn{1}{|c|}{ Statements } & $\begin{array}{c}\text { Strongly } \\
\text { agree }\end{array}$ & Agree & Neutral & Disagree & $\begin{array}{c}\text { Strongly } \\
\text { disagree }\end{array}$ & M & SD \\
\hline $\begin{array}{l}\text { I had high motivation to do the } \\
\text { project which was based on the } \\
\text { potential of my region }\end{array}$ & $\begin{array}{c}31 \\
(60.8 \%)\end{array}$ & $\begin{array}{c}20 \\
(39.2 \%)\end{array}$ & $\begin{array}{c}0 \\
(0 \%)\end{array}$ & $\begin{array}{c}0 \\
(0 \%)\end{array}$ & $\begin{array}{c}0 \\
(0 \%)\end{array}$ & 4.61 & 0.49 \\
\hline $\begin{array}{l}\text { I had a high interest to do the } \\
\text { project which was based on the } \\
\text { potential of my region }\end{array}$ & $\begin{array}{c}29 \\
(56.9 \%)\end{array}$ & $\begin{array}{c}22 \\
(43.1 \%)\end{array}$ & $\begin{array}{c}0 \%) \\
(0 \%)\end{array}$ & $\begin{array}{c}0 \\
(0 \%)\end{array}$ & 4.57 & 0.50 \\
\hline $\begin{array}{l}\text { I got a better understanding on } \\
\text { the implemented knowledge for } \\
\text { real life when I did the project } \\
\text { which was based on the potential } \\
\text { of my region }\end{array}$ & $\begin{array}{c}28 \\
(54.9 \%)\end{array}$ & $\begin{array}{c}19 \\
(37.3 \%)\end{array}$ & $\begin{array}{c}4 \\
(7.8 \%)\end{array}$ & $\begin{array}{c}0 \\
(0 \%)\end{array}$ & $\begin{array}{c}0 \\
(0 \%)\end{array}$ & 4.47 & 0.64 \\
\hline $\begin{array}{l}\text { I would learn more when I did } \\
\text { the project which was relevant to } \\
\text { the real world rather than the free } \\
\text { theme. }\end{array}$ & $\begin{array}{c}23 \\
(45.1 \%)\end{array}$ & $\begin{array}{c}21 \\
(41.1 \%)\end{array}$ & $\begin{array}{c}7 \\
(13.7 \%)\end{array}$ & $\begin{array}{c}0 \\
(0 \%)\end{array}$ & $\begin{array}{c}0 \\
(0 \%)\end{array}$ & 4.31 & 0.71 \\
\hline $\begin{array}{l}\text { The project which was based on } \\
\text { the potential of my region is very } \\
\text { beneficial }\end{array}$ & $\begin{array}{c}26 \\
(51 \%)\end{array}$ & $\begin{array}{c}20 \\
(39.2 \%)\end{array}$ & $\begin{array}{c}5 \\
(9.8 \%)\end{array}$ & $\begin{array}{c}0 \\
(0 \%)\end{array}$ & $\begin{array}{c}0 \\
(0 \%)\end{array}$ & 4.41 & 0.67 \\
\hline $\begin{array}{l}\text { Project-based learning is } \\
\text { enjoyable. }\end{array}$ & $\begin{array}{c}27 \\
(52.9 \%)\end{array}$ & $\begin{array}{c}19 \\
(37.3 \%)\end{array}$ & $\begin{array}{c}5 \\
(9.8 \%)\end{array}$ & $\begin{array}{c}0 \\
(0 \%)\end{array}$ & $\begin{array}{c}0 \\
(0 \%)\end{array}$ & 4.43 & 0.67 \\
\hline
\end{tabular}

Table 3. The data analysis of students' perceptions

The projects based on the potential of the students' regions can raise students' perceptions in terms of motivation, interest, real-world, learning more lecture, very beneficial, and enjoyable. These projects stimulate their motivation and interest to develop the potential in their regions. $60.8 \%$ of the students strongly agreed and $39.2 \%$ of them agreed. It means that all students have high motivation to do the project of the potential in their regions. In line with it, all students also have a high interest to do the projects which are shown by the result that $56.9 \%$ of them strongly agreed and $43.1 \%$ of them agreed. The interview results also show that the factors influencing high motivation and interest of the students are that the idea of the project is based on the potential sources of the students' region and the students themselves figure out the machine they want to make as the project. The concern of the development of their region fosters the natural motivation of the students. This is similar to the finding reported by 
Pucher, Mense and Wahl (2002) that if the students get the freedom to choose their project, their instinct of motivation will be higher. This is in line with Chiang and Lee (2016) who state that students' motivation can be increased through the implementation of PjBL.

Furthermore, doing this project also raise students' perceptions of the real world, learning more lectures, very beneficial, and enjoyable. The result shows that most of the students preferred to choose "strongly agree" than other categories. A study by Sang and Van (2016) was also conducted on PjBL but the projects were given there were not specifically based on the students' region potential. The study also used a questionnaire that was distributed to 50 respondents who were students of Universiti Teknologi Malaysia. However, the result of this study shows a higher percentage. It implies that the project based on the potential of the students' region is more effective to raise the students' perception of real-world, learning more lecture, very beneficial, and enjoyable than the project which is not specifically based on the potential of the students' region is. The comparison of both results is shown in Figure 2.

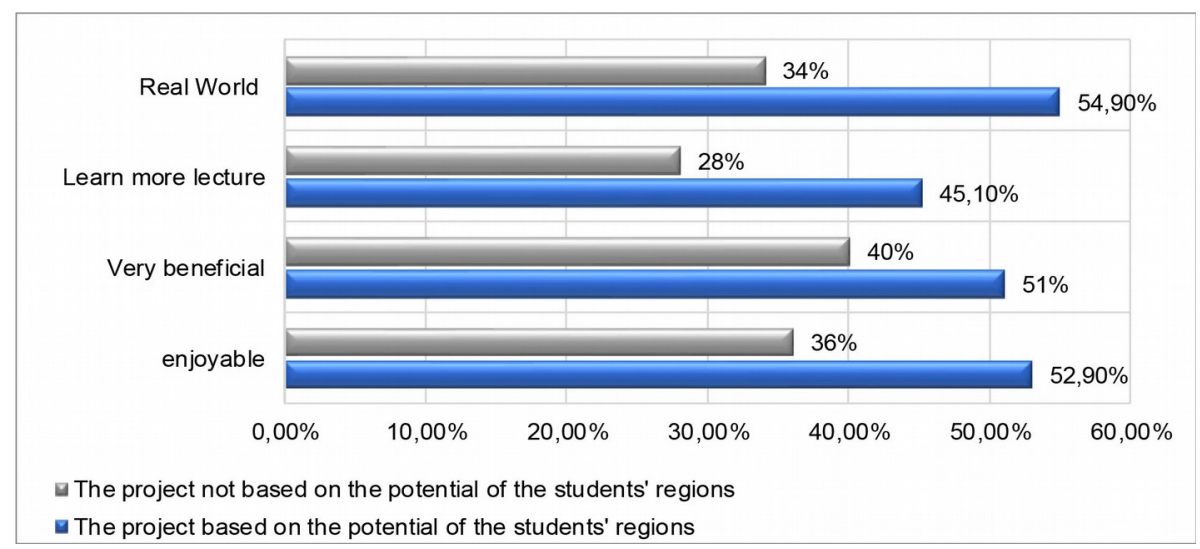

Figure 2. The comparison on students' perceptions of learning

\subsection{Students' Perceptions of Soft Skills Acquisition Toward the Implementation of PjBL with the Project Based on the Potential of the Students' Regions}

The project-based on the potential of the students' regions as the implementation of $\mathrm{PjBL}$ in learning activity can effectively develop students' soft skills. This is in line with the findings of Musa, Mufti, Latiff and Amin (2011) which state that PjBL has a contribution in developing students' soft skills. Idrus and Abdullah (2018) also add that students' soft skills can be improved through PjBL.

\subsubsection{The Student's Perceptions of Teamwork}

The result of data analysis of students' perceptions of teamwork skills shows that the "strongly agree" score is the highest percentage among all items as shown in Table 4. Moreover, "I learned how to listen actively to my group members" item also reaches the highest value $(M=4.33)$ in which $49 \%$ of students strongly agreed and $39.2 \%$ of students agreed. This was followed by "I learned how to be assertive when exchanging ideas with group members" $(M=4.24)$, "I learned that good teamwork contributed to a successful outcome of the project" $(M=4.20)$, and "I learned how to ask and respond appropriately among group members" $(M=4.18)$.

The result of this study showed that the project can develop students' teamwork skills in PjBL. Alves, Mesquita, Moreira and Fernandes (2012) find that high motivation, active learning in team, and feeling enjoyable in sharing the jobs in PjBL activities lead to students' high teamwork skills. Jun (2010) also finds that through the project on PjBL, students face many problems and they can work as a team to solve them. High motivation and interest in doing this project make students improve their teamwork skills. Jalinus, Syahril, Nabawi and Arbi (2020) states that PjBL gives students experience to run the project in group so that they get soft skill of teamwork. Besides, Wiewiora, Chang and Smidt (2020) say that PjBL is the function of individual internal cognitive process, project and team learning interpretation and 
integration, and organization ability to integrate learning into practice. Sang and Van (2016) present the comparison of the percentage for students who agree on teamwork skills between the project which is and is not based on the potential of the students' regions. The comparison is described in Figure 3. There are three out of four teamwork skills on the project based on the potential of the students' regions get higher percentage than those of another project is. For "contributes" skill, the project which is not based on the potential of the students' regions is higher (46\%) than another project is (43.1). However, the difference is not significant.

\begin{tabular}{|c|c|c|c|c|c|c|c|}
\hline Items & $\begin{array}{c}\text { Strongly } \\
\text { agree }\end{array}$ & Agree & Neutral & Disagree & $\begin{array}{l}\text { Strongly } \\
\text { disagree }\end{array}$ & $\mathbf{M}$ & SD \\
\hline $\begin{array}{l}\text { I learned how to listen actively to } \\
\text { my group members }\end{array}$ & $\begin{array}{c}25 \\
(49 \%)\end{array}$ & $\begin{array}{c}20 \\
(39.2 \%)\end{array}$ & $\begin{array}{c}4 \\
(7.8 \%)\end{array}$ & $\begin{array}{c}2 \\
(3.9 \%)\end{array}$ & $\begin{array}{c}0 \\
(0 \%)\end{array}$ & 4.33 & 0.79 \\
\hline $\begin{array}{l}\text { I learned how to ask and respond } \\
\text { appropriately among group } \\
\text { members }\end{array}$ & $\begin{array}{c}22 \\
(43.1 \%)\end{array}$ & $\begin{array}{c}19 \\
(37.3 \%)\end{array}$ & $\begin{array}{c}7 \\
(13.7 \%)\end{array}$ & $\begin{array}{c}3 \\
(5.9 \%)\end{array}$ & $\begin{array}{c}0 \\
(0 \%)\end{array}$ & 4.18 & 0.89 \\
\hline $\begin{array}{l}\text { I learned how to be assertive when } \\
\text { exchanging ideas with group } \\
\text { members }\end{array}$ & $\begin{array}{c}23 \\
(45.1 \%)\end{array}$ & $\begin{array}{c}18 \\
(35.3 \%)\end{array}$ & $\begin{array}{c}9 \\
(17.6 \%)\end{array}$ & $\begin{array}{c}1 \\
(2 \%)\end{array}$ & $\begin{array}{c}0 \\
(0 \%)\end{array}$ & 4.24 & 0.81 \\
\hline $\begin{array}{l}\text { I learned that good team-work } \\
\text { contributes to the successful } \\
\text { outcome of the project }\end{array}$ & $\begin{array}{c}22 \\
(43.1 \%)\end{array}$ & $\begin{array}{c}19 \\
(37.3 \%)\end{array}$ & $\begin{array}{c}8 \\
(15.7 \%)\end{array}$ & $\begin{array}{c}2 \\
(3.9 \%)\end{array}$ & $\begin{array}{c}0 \\
(0 \%)\end{array}$ & 4.20 & 0.85 \\
\hline
\end{tabular}

Table 4. The data analysis of students' perceptions of teamwork

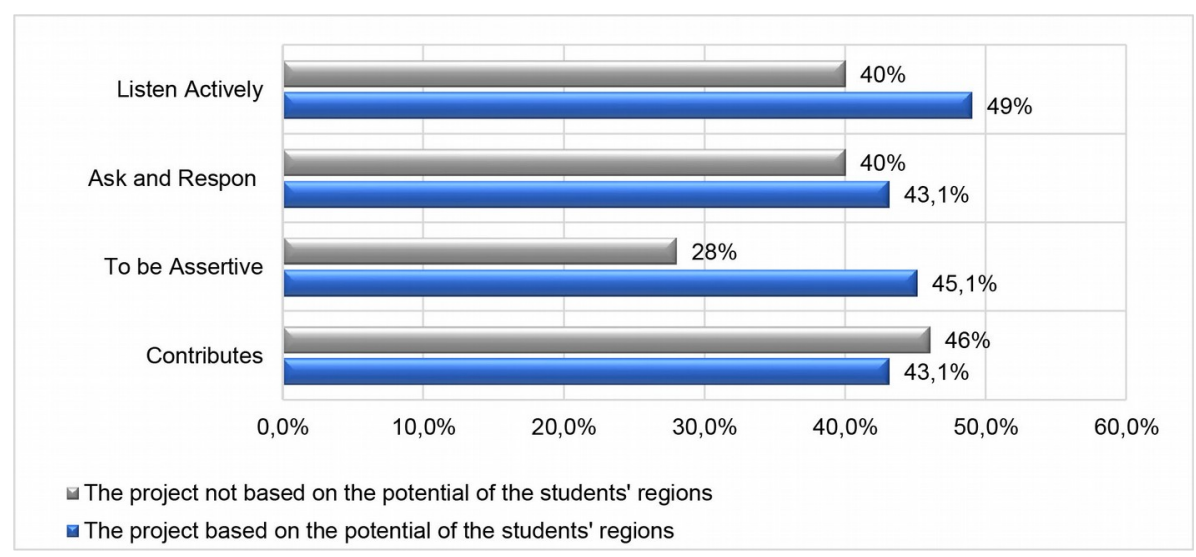

Figure 3. The comparison on students' perception of teamwork skill

\subsubsection{The Students' Perceptions of the Project Management}

The data analysis of students' perceptions of project management is presented in Table 5. It can be observed that "I learned how to brainstorm and forward ideas appropriately with group members" $(M=4.43)$, followed by, "I learned how to identify the relevant ideas from reading materials regarding project work" $(M=4.37)$, "I was confident to give suggestion and forward ideas appropriately with group members" $(M=31)$, and "I understood and was able to gather information for the project" item gets the highest value $(M=4.27)$,

From the data analysis, the project based on the potential of students' region can develop students' project management. This finding is supported by Ríos-Carmenado, Lopez and Garcia (2015), who state that $\mathrm{PjBL}$ implemented in higher education has a role to educate the students to be modern engineers with good project management skills. Moreover, Amaral, Goncalves and Hess (2015) also find that PjBL provides students with the ways to perform professional project management because it gives practical experience. The comparison of the four items of project management between the project based on the potential of the students' regions and the research finding of Sang and Van (2016) which the project is 
not based on the potential of students' region can be seen in Figure 4. All students who did the project based on the potential of their regions agreed to the four items on project management. It was because in $\mathrm{PjBL}$, they got experience about the project management when debriefing competencies and also due to the effect of individual learning during the project which develops the students' project management skills. High motivation and interest to develop the potential of their regions assisted students to find out the relevant ideas and do the project seriously. The operational procedure of the project includes writing the project proposal, setting the schedule, and sharing ideas to achieve the best project needed to achieve the success of the project.

\begin{tabular}{|l|c|c|c|c|c|c|c|}
\hline \multicolumn{1}{|c|}{ Items } & $\begin{array}{c}\text { Strongly } \\
\text { agree }\end{array}$ & Agree & Neutral & Disagree & $\begin{array}{c}\text { Strongly } \\
\text { disagree }\end{array}$ & M & SD \\
\hline $\begin{array}{l}\text { I was confident to give suggestion } \\
\text { and forward ideas appropriately } \\
\text { with group members }\end{array}$ & $\begin{array}{c}25 \\
(49 \%)\end{array}$ & $\begin{array}{c}18 \\
(35,3 \%)\end{array}$ & $\begin{array}{c}7 \\
(13.7 \%)\end{array}$ & $\begin{array}{c}1 \\
(2 \%)\end{array}$ & $\begin{array}{c}0 \\
(0 \%)\end{array}$ & 4.31 & 0.79 \\
\hline $\begin{array}{l}\text { I learned how to brainstorm and } \\
\text { forward ideas appropriately with } \\
\text { group members }\end{array}$ & $\begin{array}{c}26 \\
(51 \%)\end{array}$ & $\begin{array}{c}21 \\
(41.2 \%)\end{array}$ & $\begin{array}{c}4 \\
(7.8 \%)\end{array}$ & $\begin{array}{c}0 \\
(0 \%)\end{array}$ & $\begin{array}{c}0 \\
(0 \%)\end{array}$ & 4.43 & 0.64 \\
\hline $\begin{array}{l}\text { I understood and was able to } \\
\text { gather information for the project }\end{array}$ & $\begin{array}{c}24 \\
(47.1 \%)\end{array}$ & $\begin{array}{c}18 \\
(35,3 \%)\end{array}$ & $\begin{array}{c}8 \\
(15.7 \%)\end{array}$ & $\begin{array}{c}1 \\
(1.9 \%)\end{array}$ & $\begin{array}{c}0 \\
(0 \%)\end{array}$ & 4.27 & 0.80 \\
\hline $\begin{array}{l}\text { I learned how to identify the } \\
\text { relevant ideas from reading } \\
\text { materials regarding the project. }\end{array}$ & $\begin{array}{c}25 \\
(49 \%)\end{array}$ & $\begin{array}{c}20 \\
(39.2 \%)\end{array}$ & $\begin{array}{c}6 \\
(11.8 \%)\end{array}$ & $\begin{array}{c}0 \\
(0 \%)\end{array}$ & $\begin{array}{c}0 \\
(0 \%)\end{array}$ & 4.37 & 0.69 \\
\hline
\end{tabular}

Table 5. The data analysis of students' perceptions of project management

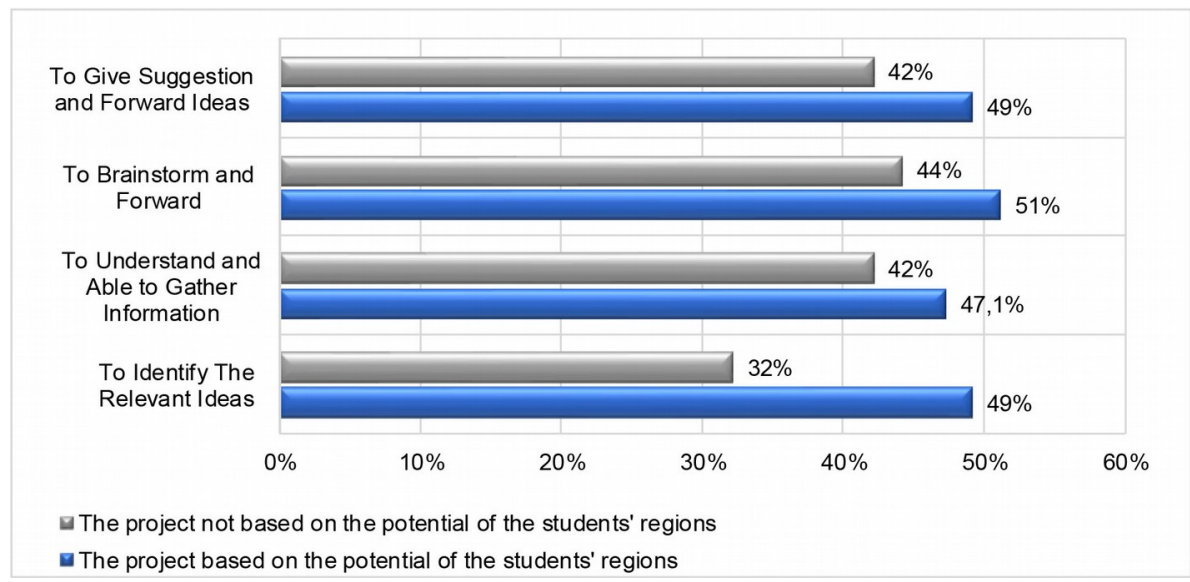

Figure 4. The comparison on students' perception of Project Management

\subsubsection{Students' Perceptions of Communication Skills}

Table 6 presents the data analysis of students' perceptions of communication skills. From Table 6, it can be seen that the highest value is on "I learned to organize ideas in preparing and writing the executive summary" (M=4.33), This is followed by, "I learned how to write project reports based on the findings" $(M=4.29)$, "I learned to write communicative sentences in my project assignment and report assignments" item $(M=4.27)$. "I made a good format and writing style to my proposal and project report according to the template given" $(M=4.27)$, and "I familiarized myself with the format and writing style of the proposal and project report template" $(M=4.15)$.

Learning activities implementing PjBL with the project based on the potential of students' regions can develop students' communication skills. This finding is supported by Magleby and Furse (2007) who find that $\mathrm{PjBL}$ implemented to engineering students is able to increase their communication skill. Communication skill refers to both spoken and written. Written communication can be seen in the 
students' project proposals and reports. Meanwhile, the spoken communication can be shown on how the students ensure the lecturer about the machine they have drawn and in their project presentation. It can be explained from Figure 5 that students' communication skills on PjBL with the project based on the potential of the students' regions is higher than the research finding of Sang and Van (2016). It is assumed that the students understood why they did the project as it came from their regions. It can also be seen through their project report presentation. Because of the high motivation and interest, the students understood what they did and were able to present it well.

\begin{tabular}{|l|c|c|c|c|c|c|c|}
\hline \multicolumn{1}{|c|}{ Item } & $\begin{array}{c}\text { Strongly } \\
\text { agree }\end{array}$ & Agree & Neutral & Disagree & $\begin{array}{c}\text { Strongly } \\
\text { disagree }\end{array}$ & M & SD \\
\hline $\begin{array}{l}\text { I learned to write communicative } \\
\text { sentences in my project } \\
\text { assignments and report } \\
\text { assignments }\end{array}$ & $\begin{array}{c}23 \\
(45.1 \%)\end{array}$ & $\begin{array}{c}22 \\
(43.1 \%)\end{array}$ & $\begin{array}{c}3 \\
(5.9 \%)\end{array}$ & $\begin{array}{c}3 \\
(5.9 \%)\end{array}$ & $\begin{array}{c}0 \\
(0 \%)\end{array}$ & 4.27 & 0.82 \\
\hline $\begin{array}{l}\text { I made a good format and writing } \\
\text { style to my proposal and project } \\
\text { report according to the given } \\
\text { template }\end{array}$ & $\begin{array}{c}24 \\
(47.1 \%)\end{array}$ & $\begin{array}{c}21 \\
(41.2 \%)\end{array}$ & $\begin{array}{c}2 \\
(3.9 \%)\end{array}$ & $\begin{array}{c}4 \\
(7.8 \%)\end{array}$ & $\begin{array}{c}0 \\
(0 \%)\end{array}$ & 4.27 & 0.87 \\
\hline $\begin{array}{l}\text { I familiarized myself with the } \\
\text { format and writing style of the } \\
\text { proposal and project report } \\
\text { template }\end{array}$ & $\begin{array}{c}22 \\
(43.1 \%)\end{array}$ & $\begin{array}{c}19 \\
(35.3 \%)\end{array}$ & $\begin{array}{c}7 \\
(13.7 \%)\end{array}$ & $\begin{array}{c}3 \\
(5.9 \%)\end{array}$ & $\begin{array}{c}0 \\
(0 \%)\end{array}$ & 4.17 & 0.88 \\
\hline $\begin{array}{l}\text { I learned to organize ideas in } \\
\text { preparing and writing the } \\
\text { executive summary }\end{array}$ & $\begin{array}{c}25 \\
(49 \%)\end{array}$ & $\begin{array}{c}20 \\
(39.2 \%)\end{array}$ & $\begin{array}{c}4 \\
(7.9 \%)\end{array}$ & $\begin{array}{c}2 \\
(0 \%)\end{array}$ & $\begin{array}{c}0 \\
(3.9 \%)\end{array}$ & 4.33 & 0.79 \\
\hline $\begin{array}{l}\text { I learned how to write project } \\
\text { reports based on the findings }\end{array}$ & $\begin{array}{c}26 \\
(51 \%)\end{array}$ & $\begin{array}{c}17 \% \\
(33.3 \%)\end{array}$ & $\begin{array}{c}5 \\
(9.8 \%)\end{array}$ & $\begin{array}{c}3 \\
(5.9 \%)\end{array}$ & $\begin{array}{c}0 \\
(0 \%)\end{array}$ & 4.29 & 0.87 \\
\hline
\end{tabular}

Table 6. The data analysis of students' perceptions of communication skills

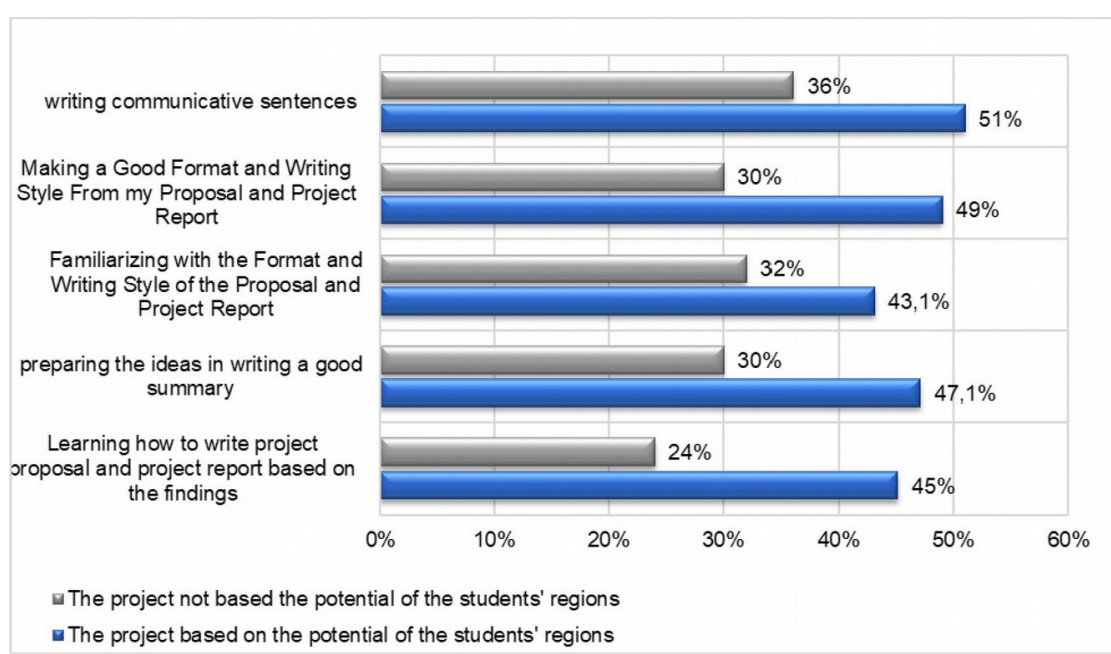

Figure 5. The comparison of the percentage for students who agreed on Communication skill

\subsubsection{The students' Perceptions of Interpersonal Skills}

The data analysis of students' perceptions of interpersonal skills can be seen in Table 7. It shows that "I improved my social skills when meeting and talking with lecturers and coworkers in the group study" got the highest value $(M=4.39)$, followed by "I learned how to interrupt appropriately during interactions" $(M=4.23)$, "I learned to use formal and informal language in the appropriate context of discourse" $(M=4.21)$, "I became more perceptive and sensitive to the needs of others during group work" $(M=4.15)$, and "I learned to work successfully with students from different social and cultural groups" ( $M=4.09)$. 
The result shows that students' interpersonal skills can be developed by doing the project on the potential of the students' regions. Figure 6 reveals the comparison between this research finding and that of Sang and Van (2016). The connection of students in a team during doing the project shaped their interpersonal skills because each of them had high motivation and interest to develop their regions through this project. The students concerned about their team needs so that it increased the social skill among them. The language they used to communicate also contributed to the learning activities. The students were expected to be able to use appropriate language in both formal and informal situations to improve students' interpersonal skills as well as communication and teamwork skills. A successful project is the main goal to develop their regions. This finding also answers the question of research conducted by Musa et al. (2011) about learning innovation on PjBL to improve students' interpersonal skills. On that research, the project was not based on the potential of students' regions so it did not significantly improve student's interpersonal skills. It was assumed that the students' communication skills were lower.

\begin{tabular}{|l|c|c|c|c|c|c|c|}
\hline \multicolumn{1}{|c|}{ Item } & $\begin{array}{c}\text { Strongly } \\
\text { agree }\end{array}$ & Agree & Neutral & Disagree & $\begin{array}{c}\text { Strongly } \\
\text { disagree }\end{array}$ & M & SD \\
\hline $\begin{array}{l}\text { I became more perceptive and } \\
\text { sensitive to the needs of others } \\
\text { during group work }\end{array}$ & $\begin{array}{c}21 \\
(41.2 \%)\end{array}$ & $\begin{array}{c}19 \\
(37.3 \%)\end{array}$ & $\begin{array}{c}9 \\
(17.6 \%)\end{array}$ & $\begin{array}{c}2 \\
(3.9 \%)\end{array}$ & $\begin{array}{c}0 \\
(0 \%)\end{array}$ & 4.15 & 0.85 \\
\hline $\begin{array}{l}\text { I learned to work successfully } \\
\text { with students from different } \\
\text { social and cultural groups }\end{array}$ & $\begin{array}{c}20 \\
(39.2 \%)\end{array}$ & $\begin{array}{c}18 \\
(35,2 \%)\end{array}$ & $\begin{array}{c}11 \\
(21.6 \%)\end{array}$ & $\begin{array}{c}2 \\
(3.9 \%)\end{array}$ & $\begin{array}{c}0 \\
(0 \%)\end{array}$ & 4.09 & 0.87 \\
\hline $\begin{array}{l}\text { I learned to use formal and } \\
\text { informal language in the } \\
\text { appropriate context of } \\
\text { discourse }\end{array}$ & $\begin{array}{c}23 \\
(45.1 \%)\end{array}$ & $\begin{array}{c}18 \\
(35.3 \%)\end{array}$ & $\begin{array}{c}8 \\
(15.6 \%)\end{array}$ & $\begin{array}{c}2 \\
(3.9 \%)\end{array}$ & $\begin{array}{c}0 \\
(0 \%)\end{array}$ & 4.21 & 0.85 \\
\hline $\begin{array}{l}\text { I improved my social skills } \\
\text { when meeting and talking with } \\
\text { lecturers and coworkers in the } \\
\text { group study }\end{array}$ & $\begin{array}{c}25 \\
(49 \%)\end{array}$ & $\begin{array}{c}22 \\
(43.1 \%)\end{array}$ & $\begin{array}{c}3 \\
(5.8 \%)\end{array}$ & $\begin{array}{c}1 \\
(2 \%)\end{array}$ & $\begin{array}{c}0 \\
(0 \%)\end{array}$ & 4.39 & 0.69 \\
\hline $\begin{array}{l}\text { I learned how to interrupt } \\
\text { appropriately during } \\
\text { interactions }\end{array}$ & $\begin{array}{c}23 \% \\
(45.1 \%)\end{array}$ & $\begin{array}{c}20 \\
(39.2 \%)\end{array}$ & $\begin{array}{c}5 \\
(9.8 \%)\end{array}$ & $\begin{array}{c}3 \\
(5.9 \%)\end{array}$ & $\begin{array}{c}0 \\
(0 \%)\end{array}$ & 4.23 & 0.86 \\
\hline
\end{tabular}

Table 7. The data analysis of students' perceptions of interpersonal skills

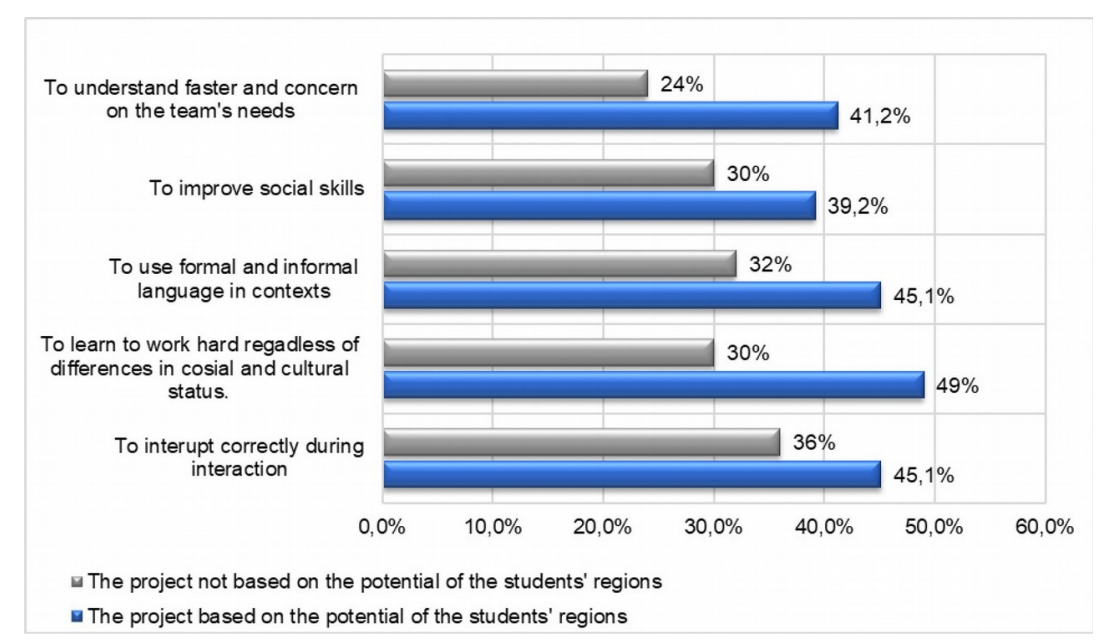

Figure 6. The comparison on students' perception of Interpersonal skill 


\subsection{The Correlation Between Learning and Soft Skills}

The Analysis results of correlation and regression between learning and soft skills are presented in Table 8. The results of the correlation analysis between student's perception of learning and teamwork showed that there was a significant effect $[\mathrm{R} 1.49=0.946, \mathrm{p}<0.005]$. The $\mathrm{p}$-value $[\mathrm{P}=0.000]$ of these two variables indicates that the null hypothesis $(\mathrm{HO})$ is rejected, while the alternative hypothesis $(\mathrm{Ha})$ is accepted. This means that the student's perception of the learning has a significant effect on their teamwork. The coefficient of determination $[\mathrm{R} 2=0.895]$ indicates that their perception of the learning has a large effect. This indicates that $89.5 \%$ of the increase in their teamwork skills is influenced by their perception of the learning. The interpretation of this relationship indicates that changes in the students' teamwork skills as the result of the student's perception of the learning are real.

The results of the correlation analysis between student's perception of learning and project management showed that there was a significant effect $[\mathrm{R} 1.49=0.952, \mathrm{p}<0.005]$. The $\mathrm{p}$-value $[\mathrm{P}=0.000]$ of these two variables indicates that the null hypothesis $(\mathrm{H} 0)$ is rejected, while the alternative hypothesis $(\mathrm{Ha})$ is accepted. This means that the student's perception of the learning has a significant effect on their project management. The coefficient of determination $[\mathrm{R} 2=0.907]$ indicates that their perception of the learning has a large effect. This shows that $90.7 \%$ of the increase in their project management skills is influenced by their perception of the learning. The interpretation of this relationship indicates that changes in the students' project management skills as a result of the student's perception of the learning are real. The results of the correlation analysis between student's perception of learning and communication skills showed that there was a significant effect $[\mathrm{R} 1.49=0.962, \mathrm{p}<0.005]$. The $\mathrm{p}$-value $[\mathrm{P}=0.000]$ of these two variables indicates that the null hypothesis $(\mathrm{H} 0)$ is rejected, while the alternative hypothesis $(\mathrm{Ha})$ is accepted, this means that the student's perception of the learning has a significant effect on their communication skills. The coefficient of determination $[R 2=0.926]$ indicates that their perception of the learning has a large effect. This indicates that $92.6 \%$ of the increase in their communication skills is influenced by their perception of the learning. The interpretation of this relationship indicates that changes in the students 'communication skills as a result of the student's perception of the learning are real. The results of the correlation analysis between student's perception of the learning and interpersonal skills showed that there was a significant effect $[R 1.49=0.948$, $\mathrm{p}<0.005]$. The $\mathrm{p}$-value $[\mathrm{P}=0.000$ ] of these two variables indicates that the null hypothesis $(\mathrm{H} 0)$ is rejected, while the alternative hypothesis $(\mathrm{Ha})$ is accepted. This means that the student's perception of the learning has a significant effect on their interpersonal skills. The coefficient of determination $[R 2=0.899]$ shows that their perception of the learning has a large effect. This shows that $89.9 \%$ of the increase in their interpersonal skills is influenced by their perception of the learning. The interpretation of this relationship indicates that changes in the students' interpersonal skills as a result of the student's perception of the learning are real. Based on the results of the analysis, there is a significant relationship between learning and soft skills acquired by the students.

\begin{tabular}{|c|l|r|r|r|r|r|}
\hline \multicolumn{2}{|c|}{ Variable } & & & & & \\
\hline \multicolumn{1}{|c|}{ Independent } & \multicolumn{1}{|c|}{ Dependents } & \multicolumn{1}{c|}{ R } & R Square & Sig. F Change & \multicolumn{1}{c|}{ df1 } & df2 \\
\hline \multirow{3}{*}{$\begin{array}{l}\text { Student's perceptions } \\
\text { of the learning }\end{array}$} & Teamwork & $.946^{\mathrm{a}}$ & .895 & .000 & 1 & 49 \\
\cline { 2 - 8 } & Project management & $.952^{\mathrm{a}}$ & .907 & .000 & 1 & 49 \\
\cline { 2 - 8 } & Communication skills & $.962^{\mathrm{a}}$ & .926 & .000 & 1 & 49 \\
\cline { 2 - 8 } & Interpersonal skills & $.948^{\mathrm{a}}$ & .899 & .000 & 1 & 49 \\
\hline
\end{tabular}

Table 8 . The Relationship between positive perception and soft skills

\subsection{Reporting Phase of Content Analysis}

$\mathrm{PjBL}$ has a concept to organize learning in the project that requires students to participate in responding to thinking skills and it can improve students' skills with professional activities. $\mathrm{PjBL}$ is one of the models that can be applied in conducting the assignment of developing the potential region. The skills processes that occur in implementing PjBL for the regional potential assignment are independent learning, project management, 
collaboration, communication, and collaborative knowledge construction. Based on the analysis results of students' interview answering that have been conducted. It can be categorized to be four topics as follows: debriefing of student's competencies, student centered learning, the project based on potential area effective to motivate and interest student, and creativity in doing the project to develop the potential area.

\subsubsection{Debriefing of Students' Competencies and Skills}

One of the advantages of PjBL from Jalinus and Nabawi (2018) is debriefing students' competencies and skills before they do the project which is done in the second and the third syntax. Students were provided with the competencies and knowledge about drawing a machine or tool design. An example of a detailed drawing of a machine was shown, and then the lecturer and the students discussed it together. The drawing was a machine design taken from the potential in the students' regions. The lecturer and the students wrote the proposal together. The proposal consists of analyzing the potential area, formulating a solution such as a machine or a tool that could develop the area, sketching the design of the machine, setting the specifications and parts of the machine. The practice of drawing details of the machine was done through the tutorial. These activities are aimed at helping the students do the project successfully.

I-2 : "In the beginning, I thought doing this project was difficult, especially when you had to find out the potential source of your region. But, after the debriefing of competencies and skills, I knew how to do it".

I-3 : "Writing a project proposal and report which were done together before doing the project helped me to write them well”.

I-5 : "The practice of writing the proposal dan detail drawing of a machine to develop the potential in my region helped me to do the project".

I-15: "I have understood how to identify the local potential which would be developed after getting the competency training of project task arrangement."

\subsubsection{Student-Centered Learning}

Student-centered learning occurred when the students did the project in designing the project-based theme activity, making the project proposal, executing the tasks of projects, and presenting the project report. In a debriefing of students' competencies and skills, the lecturer was actively involved in learning activities such as giving examples on how to write the project proposal and project report, formulating the solution by designing the machine or tool, and tutoring the process of drawing the machine. In doing the projects, the students were active to analyze their potential in their area, formulating the machine to draw, writing the project proposal, sketching the details of the drawing, and presenting the project report in a seminar in the classroom.

I-1 : "The basis of this project was challenging to do and takes a lot of time to finish. So, I had to study harder and provide more time to do it".

I-4 : "Providing more time to do the project was a must to finish it".

1-9 : "The project was mostly done outside the classroom as homework, group work or individual work where you had to actively find out the references.

\subsubsection{The Project-Based on Potential Area Effective to Motivate and Attract Students}

The project was done by the students aimed at developing the potential sources in their region. It was expected to increase students' motivation and interest. The development of the potential in the students' regions is to trigger the motivation and interest of students to do the projects. These projects were designed and made based on what they could find around which could be useful for their area.

I-7 : "I have high motivation and interest. The project we did is useful and can be used to develop the potential sources in our region". 
I-6 : "I was motivated to do the project because it would be useful for my region later".

I-10: "My interest in doing this project could be seen from my seriousness to do it".

The interview result shows that students have high motivation and interest to do the project. It can also be seen during the learning activities, through their seriousness and motivation to finish the project on time. The students did not only become active during the learning process in the classroom but also outside the classroom. They discussed with the lecturer about the project. Although it seemed difficult for them, they could do the project and contributed to the development of their region.

\subsubsection{Creativity in Doing the Project to Develop the Potential Area}

In doing the project, the students' digital literacy with knowledge of updated information and technology was needed to ease them operating Computer-Aided Design (CAD) software. By the software, the students could explore and express their creativity as the key in getting a successful project in Mechanical Drawing course. Student-centered learning then provided opportunities for students to implement their ideas for the project. Meanwhile, the lecturer's role was to evaluate, motivate, facilitate and be a mentor.

I-8 : "When doing this project, we had the freedom to explore our creative ideas for our project".

I-11: "We could easily find the information needed to sketch the detail of drawing of the machine from published online articles on the internet".

I-12: "The work principles of a machine could be figured out by watching Youtube, observing the process of making a machine directly, and studying the machines of research outputs in the workshop of University".

\subsection{The Students' Work Based on the Potential of Their Regions}

Each student identified the potential of their region they would develop through the designed tools or machines. The consideration in choosing the potential that would be developed was based on its urgency, problems, and benefits for the society. The following are some examples of the students' work based on the potential of their regions.

\section{Student 1}

Student 1 comes from Padang City, Sumatera Barat Province, Indonesia. Based on the result of his observation, the region has potential on tourism sector. One of several tourist attractions there, Siti Nurabaya Bridge, has a problem that is lack of visitor interest. It is caused by a lot of waste found in the river (Figure 7.a). Based on this problem, the student designed a waste cleaning boat to clean the river so it can attract the visitors to come there. The result of the design is shown in Figure 7.b.

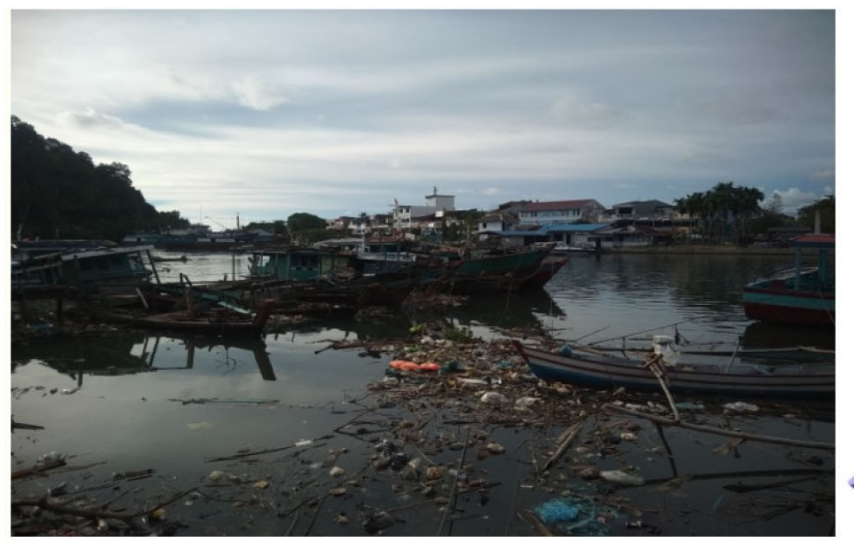

(a)

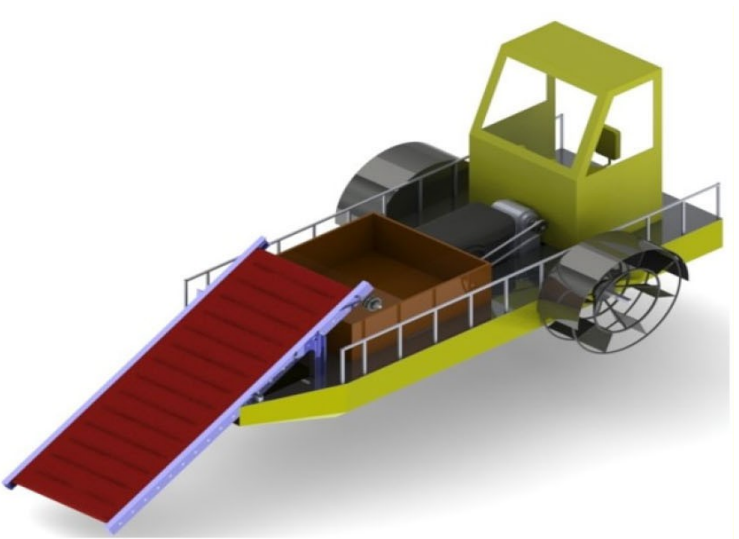

(b)

Figure 7. (a) the river in Siti Nurabaya Bridge, (b) the design of waste cleaning boat 


\section{Student 2}

Student 2 comes from Harau, Lima Puluh Kota District, Sumatera Barat Province, Indonesia. Based on his identification, the potential of his region is the existence of brick bussiness from clay but he found a problem that the bricks are still traditionally produced (Figure 8.a). It inspired him to design a solar power-machine to produce bricks so the production results will be gain optimally, more effective and efficient.

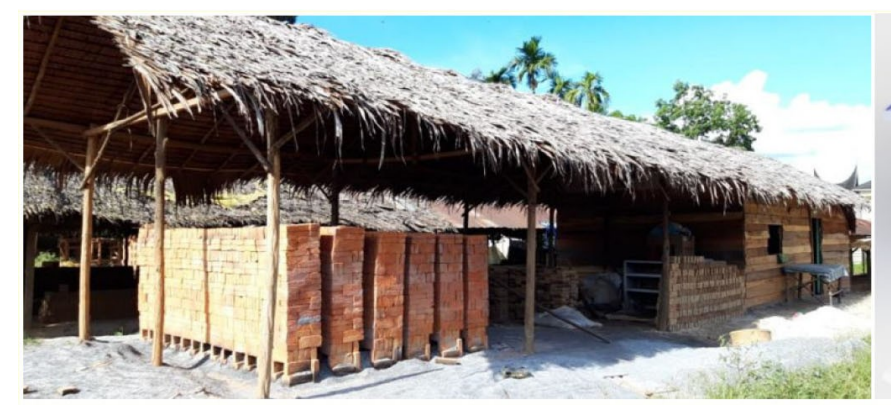

(a)

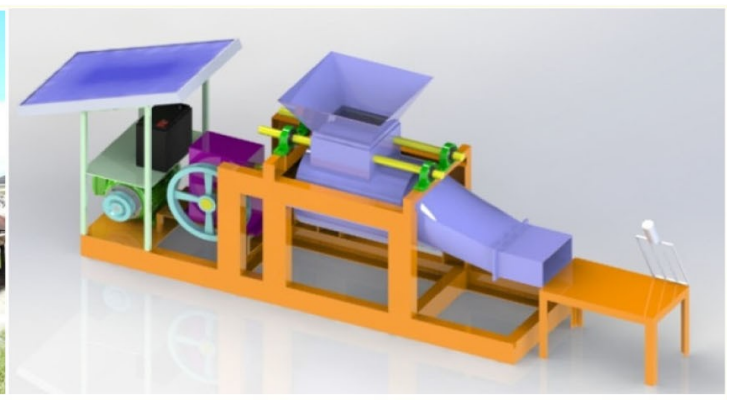

(b)

Figure 8. (a) clay bricks (b) the design of a solar power-machine

\section{Student 3}

Student 3 comes from Jujun Village, Kerinci Regency, Jambi Province, Indonesia. This village has not received electricity yet from the State Electricity Enterprise, while the people there really need it for their lives. From the result of student observation, Jujun Village has the potential on river water flow which can be used as a power plant (Figure 9.a). Therefore, the student made a design for a water wheel for a power plant (Figure 9.b).

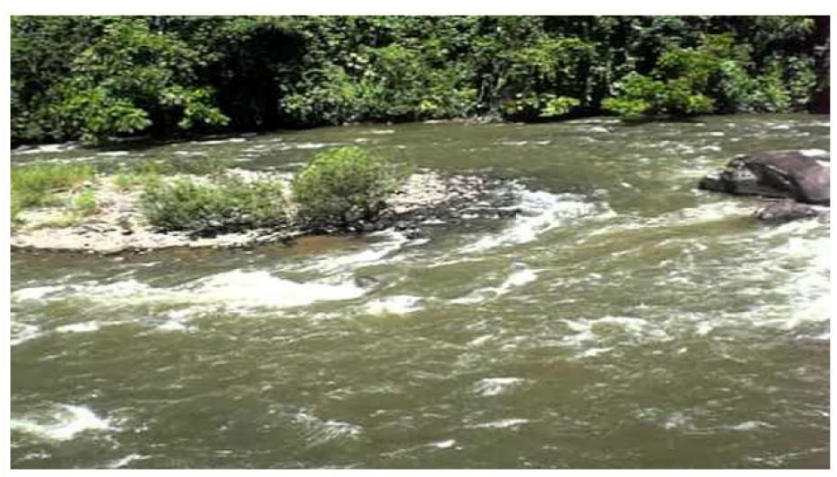

(a)

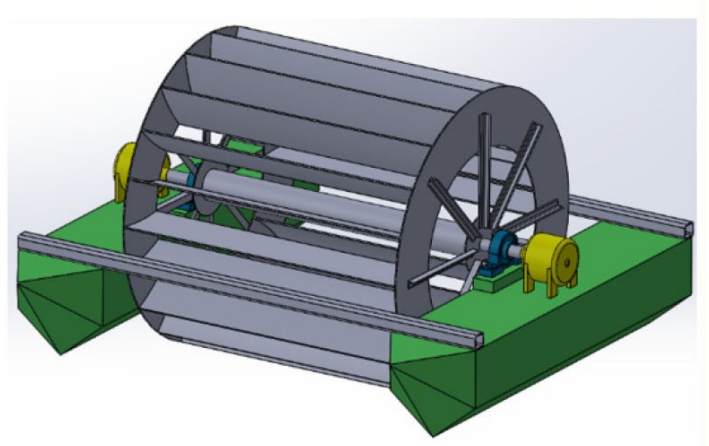

(b)

Figure 9. (a) river water flow, (b) the design of water wheel for a power plant

\section{Student 4}

Student 4 comes from Rawan Gunung Malalo Village, Pesisir Selatan Regency, Sumatera Barat Province, Indonesia. The potential of his region is the amount of cassava planted by the community there (Figure 10.a). The cassava is processed into food products. In the production process, the grating stage is done manually, so it takes too much time. Hence, he designs a cassava grater machine for an effective and efficient process, resulting in optimal production (Figure 10.b).

The students' works on Mechanical Drawing Course are in the form of a design of a device or machine. Based on the implementation of regional potential based-project, they have opportunity to develop the potential of their regions. Based on the observations of the research team, to make the students realize the design, the department motivates them to join student's creativity program organized by the 
Directorate of Learning and Student Affairs, Ministry of Education and Culture of Indonesia for funding. Proposals and designs of learning mechanical drawing are the basis for making the proposals. The creativity and innovation to develop their regional potential does not stop at lecturing activities, but they continue to look for ways so that what they have designed can actually be implemented in an effort to develop their regional potential.

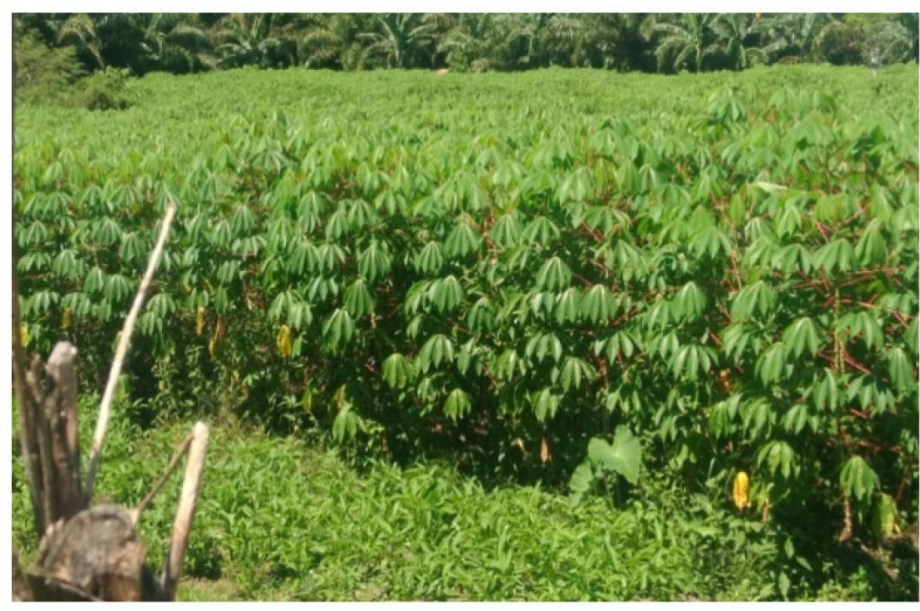

(a)

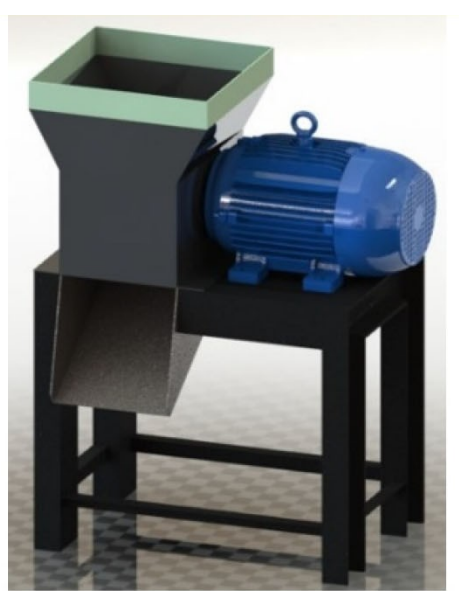

(b)

Figure 10. (a) cassava trees (b) the design of a cassava grater machine

\section{Conclusions}

$\mathrm{PjBL}$ is an appropriate learning model for engineering education. The project-based on the potential of the students' regions is an innovation in PjBL. The effect of this strategy should be disclosed. In this study, students' perceptions of learning, and soft skills were investigated to figure out the effect of $\mathrm{PjBL}$ based on the potential of students' regions. A mixed-method approach underlying quantitative and qualitative analyses was used to reveal the effect of $\mathrm{Pj} B \mathrm{BL}$ in Mechanical Drawing course focusing on students' perceptions of learning, and soft skills.

The findings of this research underline that the strategy of orienting the project to the potential of students' regions is effective in raising the students' perceptions and developing soft skills and experience. Students have perceptions such as high motivation and interest to do the project based on the potential of their regions. The project is useful to develop their regions. The students are also capable to bring their learning into practice in the real world because the project they did came from the potential of their regions they have been familiar with. The use of detail drawing of the machine affects students' perceptions of motivation, interest, real-world, learning more lecture, very beneficial, and enjoyable.

Students' high perceptions of this project are in line with the students' high soft skills. The students' high motivation and interest are very beneficial for students so that it affects their teamwork skill in doing the project. They encourage the students to be competent to do their best on the project. Moreover, students' communication skill becomes better in both spoken and written communication when they propose the project proposal and present the project report. The students also want to learn more to understand about the machine to make the project successful. Good communication skill affects the students' interpersonal skill. Therefore, the project based on the potential of the students' regions is a suitable strategy in implementing PjBL to raise students' perceptions and develop soft skills.

This study is restricted to students of Mechanical Engineering who register Mechanical Drawing course. This study is limited to 16 weeks of treatment that appropriate for the experimental study. The research uses a one-group of post-test only design in which the researcher measures dependent variables for one group of participants following a treatment. The change in the independent and intervening variables 
cannot be identified through this study. So, other factors to PjBL's treatment have not been conducted yet in this study.

\section{Declaration of Conflicting Interests}

The authors declared no potential conflicts of interest concerning the research, authorship, and/or publication of this article.

\section{Funding}

The authors gratefully acknowledge the financial support for this work provided by Universitas Negeri Padang.

\section{References}

Alves, A.C., Mesquita, D., Moreira, F., \& Fernandes, S. (2012). Teamwork in project-based learning: engineering students perceptions of strengths and weaknesses. In Hattum-Janssen, N.V., Lima, R. M., Carvalho, D., \& Campos, L.C. (Eds.), Proceeding of the Fourth International Symposium on Project Approaches in Engineering Education. Pontifícia Universidade Católica de São Paulo, Brazil. Availabe at: http://repositorium.sdum.uminho.pt/handle/1822/36308

Amamou, S., \& Belcadhi, L.C. (2018). Tutoring in Project-based learning. Procedia Computer Science, 126, 176-185. https://doi.org/10.1016/j.procs.2018.07.221

Amaral, J.A.A.D., Goncalves, P., \& Hess, A. (2015). Creating a Project-based Learning Environment to Improve Project Management Skills of Graduate Students. Journal of Problem Based Learning in Higher Education, 3(2), 120-130.

Behroozi, M. (2014). A Survey About the Function of Technical and Vocational Education: An Empirical Study in Bushehr City. CY-ICER 2014. Procedia - Social and Behavioral Sciences, 143, 265-269. https://doi.org/10.1016/j.sbspro.2014.07.401

Bouchard, T.J. (1976). Industrial and Organizational Psychology. National Institute of Mental Health, United States of America.

Botezat, E.A., \& Benea, C.B. (2012). Stimulating the Potential of Local Resources in order to achieve Competitiveness in Romanian Tourism, Emerging Markets Queries in Finance and Business. Procedia Economics and Finance, 3, 1256-1261. https://doi.org/10.1016/S2212-5671(12)00305-X

Burla, L., Knierim, B., Barth, K.L., Duetz, M., \& Abel, T. (2008). From the text to coding: Intercoder reliability assessment in qualitative content analysis. Nursing Research, 57, 113-117. https://doi.org/10.1097/01.NNR.0000313482.33917.7d

Campbell, D.T., \& Stanley, J.C. (1966). Experimental and quasi-experimental designs for research. Chicago, IL: Rand McNally \& Company.

Castaldi, P., \& Mimmo, N. (2019). An experience of project-based learning in aerospace engineering. $21^{1 t}$ IFAC Symposium on Automatic Control in Aerospace, 52(12), 484-489.

https://doi.org/10.1016/j.ifacol.2019.11.290

Cifrian, E., Andres, A., Galán, B., \& Viguri, J.R. (2020). Integration of different assessment approaches: application to a project-based learning engineering course. Education for Chemical Engineers, 31, 62-75. https://doi.org/10.1016/j.ece.2020.04.006

Chiang, C.L., \& Lee. H. (2016). The effect of project-based learning on learning motivation and problem-solving ability of vocational high school students. International Journal of Information and Education Technology, 6(9), 709-712. https://doi.org/10.7763/IJIET.2016.V6.779 
Creswell, J.W., \& Plano C., V. (2011). Designing and conducting mixed methods research (2nd ed.). Thousand Oaks, CA: Sage.

Cronbach, L.J. (1951). Coefficient alpha and the internal structure of tests. Psychometrika, 16(3), $297-334$. https://doi.org/10.1007/BF02310555

Crosling, G., Nair, M., \& Vaithilingam, S. (2015). A creative learning ecosystem, quality of education and innovative capacity: A perspective from higher education. Studies in Higher Education, 40(7), 1147-1163. https://doi.org/10.1080/03075079.2014.881342

Downe-Wamboldt, B. (1992). Content analysis: Method, application, and issues. Health Care for Women International, 13, 313-321. https://doi.org/10.1080/07399339209516006

Elo, S., Kääriäinen, M., Kanste, O., Pölkki, T., Utriainen, K., \& Kyngäs, H. (2014). Qualitative content analysis: A focus on trustworthiness. Sage Open, 4(1), 1-10. https://doi.org/10.1177/2158244014522633

Elo, S., \& Kyngäs, H. (2008). The qualitative content analysis process. Journal of Advanced Nursing, 62, 107-115. https://doi.org/10.1111/j.1365-2648.2007.04569.x

Fernández-Gómez, E., Martín-Salvador, A., Luque-Vara, T., Sánchez-Ojeda, M.A., Navarro-Prado, S., \& Enrique-Mirón, C. (2020). Content validation through expert judgment of an instrument on the nutritional knowledge, beliefs, and habits of pregnant women. Nutrients, 12(4), 1-13.

https://doi.org/10.3390/nu12041136

Fjellström, M. (2014). Vocational education in practice: a study of work-based learning in a construction program at a Swedish upper secondary school. Empirical Research in Vocational Education and Training, 6(2), 1-20. https://doi.org/10.1186/1877-6345-6-2

Guo, P., Saab, N., Post, L.S., \& Admiraal, W. (2020). A review of Project-based learning in higher education: Student outcomes and measures. International Journal of Educational Research. 102, 101586. https://doi.org/10.1016/j.ijer.2020.101586

Gupta, A. (2017). Building a Green House Using Local Resources and Sustainable Technology in Jammu Region - A case Study. Energy Procedia, 115, 59-69. https://doi.org/10.1016/j.egypro.2017.05.007

Hanney, R., (2018). Doing, being, becoming: a historical appraisal of the modalities of project-based learning. Teaching in Higher Education, 23(6), 769-783. https://doi.org/10.1080/13562517.2017.1421628

Idrus, H., \& Abdullah, M.R.T.L. (2018). Implementation of PBL to enhance the soft skills of engineering students. Conference proceedings of the International Conference Humanities and Social Sciences (ICHSS) (1-13), Kuala Lumpur, Malaysia. Publish on the SHS Web Conf. 53(03008). https://doi.org/10.1051/shsconf/20185303008

Jalinus, N., \& Nabawi, R. A. (2017). Implementation of the PjBL model to Enhance Problem Solving Skill and Skill Competencies of Community College Student. Jurnal Pendidikan Vokasi. 7(3), 304-311. https://doi.org/10.21831/jpv.v7i3.14286

Jalinus, N., \& Nabawi, R.A. (2018). The instructional media development of welding practice course based on PjBL model: enhancing student engagement and student competencies. Int. J. Innovation and Learning, 24(4), 383-397. https://doi.org/10.1504/IJIL.2018.095365

Jalinus, N., Syahril, S., Nabawi, R.A., \& Arbi, Y. (2020). How project-based learning and direct teaching models affect teamwork and welding skills among students. International Journal of Innovation, Creativity and Change, 11(11), 85-111. 
Jun, H. (2010). Improving Undergraduates' Teamwork Skills by Adapting Project-based Learning Methodology. The $5^{\text {th }}$ International Conference on Computer Science \& Education (652-655). Hefei, China. https://doi.org/10.1109/ICCSE.2010.5593527

Kuppuswamy, R., \& Mhakure, D. (2020). Project-based learning in an engineering-design course developing mechanical - engineering graduates for the world of work. $30^{\text {th }}$ CIRP Design 2020, Procedia CIRP, 91, 565-570. https://doi.org/10.1016/j.procir.2020.02.215

Lapan, S.D., Quartaroli, M.T., \& Riemer, F. J. (2012). Qualitative research: An introduction to methods and designs. Jossey-Bass.

Mackenzie, A., Pidd, M., Rooksby, J., Sommerville, I., Warren, I., \& Westcombe, M. (2003). Wisdom, decision support, and paradigms of decision making. European Journal of Operational Research. 170(2006), 156-171. https://doi.org/10.1016/j.ejor.2004.07.041

Magleby, A., \& Furse, C. (2007). Improving Communication Skills Through Project-based Learning. 2007 IEEE Antennas and Propagation Society International Symposium (5403-5406). https://doi.org/10.1109/APS.2007.4396769

Milentijevic, I., Ciric, V., \& Vajinovic, O. (2008). Version control in project-based learning. Computers \& Education, 50(2008), 1331-1338. https://doi.org/10.1016/j.compedu.2006.12.010

Musa, F., Mufti, N., Latiff, R.A., \& Amin, M.M. (2011). Project-based learning (PjBL): inculcating soft

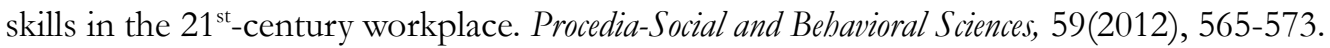
https://doi.org/10.1016/j.sbspro.2012.09.315

Neuendorf, K. (2002). The content analysis guidebook. Thousand Oaks, CA: Sage.

Nunnally, J.C., \& Bernstein, I.H. (1994). Psychometric Theory (3rd ed.) New York, NY: McGraw Hill.

Pornpimona, C., Wallapha, A., \& Prayuth, C. (2014). Strategy challenges the local wisdom applications sustainability in schools. Procedia - Social and Behavioral Sciences, 112, 626-634. https://doi.org/10.1016/j.sbspro.2014.01.1210

Pucher, R., Mense, A., \& Wahl, H. (2002). How to motivate students in project-based learning. Conference proceedings of the IEEE African 6th. George, South Africa. https://doi.org/10.1109/AFRCON.2002.1146878

Pyett, P.M. (2003). Validation of qualitative research in the "real world". Qualitative Health Research, 13, 1170-1179. https://doi.org/10.1177/1049732303255686

Qiang, S., Tan, L., Shi, X., Zhou, B., Lin, Y., \& Ma, M. (2020). A continuous design PBL machinery slide table system project in control engineering. 2020 IEEE 29th International Symposium on Industrial Electronics (ISIE) (425-429), Delft, Netherlands. https://doi.org/10.1109/ISIE45063.2020.9152234

Rambocas, M., \& Sastry, M.K.S. (2017). Teaching business management to engineers: The impact of interactive lectures. IEEE Transactions on Education, 60(3), 212-220. https://doi.org/10.1109/TE.2016.2637327

Requies, J.M., Agirre, I., Barrio, V.L., \& Graells, M. (2018). Evolution of project-based learning in small groups in environmental engineering course. Journal of Technology and Science Education, 8(1) 45-62. https://doi.org/10.3926/jotse.318

Ríos-Carmenado, I.D.L., Lopez, F.R., \& Garcia, C.P. (2015). Promoting Professional Project Management Skills in Engineering Higher Education: Project-based Learning (PBL) Strategy. International Journal of Engineering Education, 31(1) 184-198.

Sang, V.N., \& Van, N.T. (2016). Student Perception on Using Project-Based Learning (PjBL): A Case Study in Universiti Teknologi Malaysia (UTM). The 7th International Conference on University Learning and 
Teaching (InCULT 2014) (387-397). Published by Springer. Singapore. https://doi.org/10.1007/978-981-287664-5_31

Santos, E.F.D., Goncalves, B.C.M., Oliveira, K.B., \& Silva, M.B. (2018). Project-based learning applied to technical drawing. Creative Education, 9, 479-496. https://doi.org/10.4236/ce.2018.93034

Schreier, M. (2012). Qualitative content analysis in practice Thousand Oaks, CA: Sage.

Sharma, A., Dutt, H., Sai, C.N.V., \& Naik, S.M. (2020). Impact of Project-Based Learning Methodology in Engineering. Procedia Computer Science, 172, 922-926. https://doi.org/10.1016/j.procs.2020.05.133

Syahril, S., Nabawi, R.A., \& Prasetya, F. (2020). The instructional media development of mechanical drawing course based on project-based learning. International Journal of Innovation, Creativity, and Change, 11(4), 309-325.

Taber, K.S. (2018). The use of Cronbach's alpha when developing and reporting research instruments in science education. Res Sci Educ, 48, 1273-1296. https://doi.org/10.1007/s11165-016-9602-2

Uziak, J. (2016). A project-based learning approach in an engineering curriculum. Global Journal of Engineering Education, 18(2), 119-123. Available at: http://www.wiete.com.au/journals/GJEE/Publish/vol18no2/12-Uziak-J.pdf

Wiewiora, A., Chang, A., \& Smidt, M. (2020). Individual, project, and organizational learning flows within a global project-based organization: exploring what, how, and who. International Journal of Project Management, 38, 201-2014. https://doi.org/10.1016/j.ijproman.2020.03.005

Published by OmniaScience (www.omniascience.com) Journal of Technology and Science Education, 2021 (www.jotse.org)

\section{(c) $(1) \Theta$}

Article's contents are provided on an Attribution-Non Commercial 4.0 Creative commons International License. Readers are allowed to copy, distribute and communicate article's contents, provided the author's and JOTSE journal's names are included. It must not be used for commercial purposes. To see the complete licence contents, please visit https://creativecommons.org/licenses/by-nc/4.0/. 